\title{
Lymphocyte and Granulocyte Phosphatidylethanolamine N-Methyltransferase: Properties and Activity in Cystic Fibrosis
}

\author{
PAMELA B. DAVIS \\ Department of Pediatrics, Case Western Reserve University School of Medicine, Cleveland, Ohio 44106
}

\begin{abstract}
Human lymphocyte and granulocyte membranes contain an enzyme, phosphatidylethanolamine $\mathrm{N}$ methyltransferase (PEMT), which catalyzes the transfer of a methyl group from S-adenosylmethionine to the polar head group of phosphatidylethanolamine to form phosphatidylmonomethylethanolamine. This enzyme, in lymphocyte membranes, has $K_{\mathrm{m}}$ for S-adenosylmethionine of 7.01 \pm 2.9 (SD) $\mu \mathrm{M}$, and specific activity $0.57 \pm 0.31 \mathrm{pmol} / \mathrm{mg}$ protein $/ 15 \mathrm{~min}$, is inhibited by $\mathrm{S}$-adenosylhomocysteine, displays optimal activity at $\mathrm{pH}$ 8.0-9.0, and is stimulated by isoproterenol in dose-dependent, propranolol-inhibitable fashion, to a lesser extent by epinephrine, but not by norepinephrine, prostaglandin $\mathrm{E}_{1}$, concanavalin $\mathrm{A}$, or adenosine $3^{\prime}: 5^{\prime}$ cyclic monophosphate, with or without phosphodiesterase inhibitors. Granulocyte membrane PEMT has $K_{m}$ for S-adenosylmethionine of $4.4 \mu \mathrm{M}$ and specific activity $0.54 \pm 0.51 \mathrm{pmol} / \mathrm{mg}$ protein $/ 15 \mathrm{~min}$, is inhibited by $\mathrm{S}$-adenosylhomocysteine, displays optimal activity at pH 8.0-9.5, and is stimulated by isoproterenol $>$ epinephrine $>$ norepinephrine, but not by prostaglandin $E_{1}$, serumtreated zymosan, formyl-methionyl-leucyl-phenylalanine, or adenosine $3^{\prime}: 5^{\prime}$ cyclic monophosphate. Because activation of PEMT reportedly contributes to several processes known to be abnormal in cystic fibrosis, including coupling of the $\beta$-adrenergic receptor to adenylate cyclase, activity of PEMT was compared in lymphocyte and granulocyte membrane preparations from cystic fibrosis patients and healthy controls, in which abnormal coupling of $\beta$-adrenergic receptor to adenylate cyclase had been demonstrated. For both cell types, the $K_{m}$ and specific activity of PEMT were comparable in normal and cystic fibrosis samples. Therefore, the hypothesis that reduced PEMT activity accounts for the impaired coupling of $\beta$-adrenergic receptor to adenylate cyclase in lymphocytes and granulocytes in cystic fibrosis is rejected. (Pediatr Res 20:1290-1296, 1986)
\end{abstract}

\section{Abbreviations}

CF, cystic fibrosis

PEMT, phosphatidylethanolamine $\mathrm{N}$-methyltransferase SAM, S-adenosylmethionine

PE, phosphatidylethanolamine

PM, phosphatidyl monomethylethanolamine

PC, phosphatidylcholine

PD, phosphatidyl N,N-dimethylethanolamine

GMPPNP, guanyl 5'yl imidodiphosphate

Received May 9. 1986: accepted July 24, 1986

Address for correspondence and reprints Pamela B. Davis, M.D., Ph.D., Pediatric Pulmonary Division. Rainbow Babies and Childrens Hospital, 2101 Adelbert Road, Cleveland, $\mathrm{OH} 44106$

This work was supported by Grant HL28386 from the National Heart, Lung, and Blood Institute.
IBMX, isobutylmethylxanthine

fMLP, formyl-methionyl-leucyl-phenylalanine

Patients with $\mathrm{CF}$ may have disordered plasma membrane function. Among the abnormalities reported are altered monovalent ion transport across respiratory and sweat duct epithelium $(1,2)$, abnormal calcium ATPase in erythrocytes and fibroblasts (3), abnormal coupling of $\beta$-adrenergic receptor to adenylate cyclase in lymphocytes and granulocytes (4), and possibly, abnormal secretory processes (5). Disorder of some fundamental membrane process in CF could affect all the other diverse functions. One possible candidate for this basic process is enzymatic phospholipid methylation.

Plasma membranes of many cell types have been reported to contain a two-enzyme system which catalyzes the sequential addition of three methyl groups to phosphatidyl ethanolamine to form phosphatidylcholine. This system has been suggested to be involved in the coupling of $\beta$-adrenergic and diazepam receptors to adenylate cyclase, regulation of $\beta$-adrenergic receptor number, activation of calcium ATPase, and the secretory process (6-13). The first enzyme, PEMT, catalyzes the transfer of a methyl group from SAM to PE to form PM. Activation of PEMT is associated with facilitated coupling of the $\beta$-adrenergic receptor to adenylate cyclase in HeLa cells, $\mathrm{C} 6$ astrocytoma cells, and rat reticulocytes (6-9), and with increase in calcium ATPase activity in human erythrocytes (10). The second enzyme in this system, PC-forming enzyme, catalyzes the transfer of two methyl groups to PM to make PC. Activation of PC-forming enzyme is associated with an increase in the apparent number of $\beta$-adrenergic receptors in rat reticulocytes or HeLa cells $(9,11)$. The process of stimulus-secretion coupling, in the mast cells and basophilic leukemia cells at least, appears to depend on activation of the phospholipid methylation system $(12,13)$ : antigen-stimulated histamine release fails to occur in rat basophilic leukemia mutant cell lines which lack either PEMT- or PC-forming enzyme, but these mutants complement each other (13).

Because the phospholipid methylation system (and particularly PEMT) affects several processes which are abnormal in CF, it deserves investigation. However, considerable controversy has arisen over this enzyme system in plasma membranes, because its activity is low, and in some prior reports unambiguous identification of radioactive product was not reported (14). Therefore, before comparison of $\mathrm{CF}$ and control samples was attempted, normal PEMT activity was characterized. Lymphocyte and granulocyte membranes were selected for study because, in $\mathrm{CF}$, they contain $\beta$-adrenergic receptors which fail to couple appropriately to adenylate cyclase (4). After the initial characterization, PEMT activity in normal and CF preparations was compared in order to test the hypothesis that reduced PEMT 
activity accounts for the $\mathrm{CF} \beta$-adrenergic coupling abnormality in lymphocytes and granulocytes. If this hypothesis is correct, either the $K_{m}$ for SAM should be increased or the specific activity of this enzyme should be reduced in CF preparations.

\section{METHODS}

Subjects. Healthy human subjects who contributed blood for the initial enzyme characterization studies were age $18-40$ yr and took no medications. Patients with CF age 20-33 yr with clinical scores (15) 62-90 also donated blood. Each patient with $\mathrm{CF}$ was matched with two age-appropriate control subjects. The characteristics of these subjects are shown in Table 1 . The study was approved by the Institutional Review Board.

Lymphocyte and granulocyte preparation. Human blood was anticoagulated with acid-citrate-dextrose and centrifuged at 200 $\times g$ for 20 min to remove platelet-rich plasma. Lymphocytes and granulocytes were separated as previously described (4). Lymphocyte membranes were prepared by homogenization of the cells, suspended in distilled water, in a Brinkman Polytron Homogenizer, setting 8 , for $15 \mathrm{~s}$, followed by centrifugation at $40,000 \times g$ for $10 \mathrm{~min}(4)$. The membranes were washed once in Tris $\mathrm{HCl}, \mathrm{pH} 8.0(25 \mathrm{mM})$ and $\mathrm{MgCl}_{2}(5 \mathrm{mM})$ buffer and finally resuspended at protein concentration $1.5-6 \mathrm{mg} / \mathrm{ml}$.

Granulocytes were resuspended in Tris $\mathrm{HCl}-50 \mathrm{mM}, \mathrm{pH} 7.4$, $\mathrm{MgCl}_{2}(10 \mathrm{mM})$, and lysed by Polytron action (15 s at setting of 8) (4). Membranes were recovered by centrifugation at $40,000 \times$ $g$ for $10 \mathrm{~min}$, washed once in Tris $\mathrm{HCl}, \mathrm{pH} 8.0(25 \mathrm{mM})$ and $\mathrm{MgCl}_{2}(5 \mathrm{mM})$ buffer and resuspended at protein concentration $2.5-6.5 \mathrm{mg} / \mathrm{ml}$.

Stimulation of cAMP production. Lymphocytes and granulocytes were stimulated to produce cAMP as previously described (4).

Phospholipid methylation assay. The usual enzyme assay contained Tris $\mathrm{HCl}$ buffer, $\mathrm{pH} 8.0,25 \mathrm{mM}, \mathrm{MgCl}_{2}$ (5 mM), PE (160 $\mu \mathrm{g}$ ) and $\left[{ }^{3} \mathrm{H}\right]-S A M$ (New England Nuclear Corp., Boston, MA) (4 $\mu \mathrm{M}$, final specific activity $2 \mathrm{Ci} / \mathrm{mmol}$ ) and $60-250 \mu \mathrm{g}$ protein in total volume $100 \mu \mathrm{l}$. The $\left[{ }^{3} \mathrm{H}\right]-\mathrm{SAM}$ was washed with $\mathrm{CHCl}_{3}$ prior to use. Incubation was at $37^{\circ} \mathrm{C}$ for $15 \mathrm{~min}$. Reaction was stopped by placing the tubes on ice and adding $2 \mathrm{ml}$ $\mathrm{CHCl}_{3}: \mathrm{CH}_{3} \mathrm{OH}: 2 \mathrm{~N} \mathrm{HCl}(6: 3: 1)$. Following vigorous mixing, the tubes were centrifuged to separate the phases $(3 \mathrm{~min}, 400 \times g$ ) and the aqueous phase removed and extracted again. The extracts were combined and washed with methanolic $\mathrm{KCl}$. The chloroform was dried with anhydrous $\mathrm{Na}_{2} \mathrm{SO}_{4}$, evaporated under a stream of nitrogen, and taken up in chloroform-methanol containing carrier phospholipids (GIBCO, Grand Island, NY) and chromatographed on thin layer plates of silica gel using $\mathrm{CHCl}_{3}: 1$ propanol:propionic acid: $\mathrm{H}_{2} \mathrm{O}, 2: 3: 2: 1$ as developer (16). The spots were visualized with $I_{2}$ vapor, scraped into scintillation vials, extracted with $1 \mathrm{ml}$ methanol, and counted in a cocktail of scintanalyzed Toluene containing Scintiprep (Fisher Chemical

Table 1. Subjects

\begin{tabular}{|c|c|c|c|c|c|c|c|c|}
\hline \multicolumn{5}{|c|}{$\mathrm{CF}$} & \multicolumn{4}{|c|}{ Control } \\
\hline No. & Age (yr) & Sex & Score* & Meds $†$ & No. & Age (yr) & Sex & Meds \\
\hline \multirow[t]{2}{*}{1} & 20 & F & 80 & $1-3$ & la & 22 & M & None \\
\hline & & & & & $1 \mathrm{~b}$ & 23 & $\mathrm{~F}$ & None \\
\hline \multirow[t]{2}{*}{2} & 24 & $\mathrm{~F}$ & 90 & None & $2 \mathrm{a}$ & 24 & M & None \\
\hline & & & & & $2 b$ & 26 & $\mathrm{~F}$ & None \\
\hline \multirow[t]{2}{*}{3} & 29 & M & 79 & 1,2 & $3 a$ & 29 & $\mathrm{M}$ & None \\
\hline & & & & & $3 b$ & 29 & $\mathrm{~F}$ & None \\
\hline \multirow[t]{2}{*}{4} & 33 & M & 62 & $1,2,4-6$ & $4 a$ & 32 & $\mathrm{~F}$ & None \\
\hline & & & & & $4 b$ & 38 & $\mathrm{~F}$ & None \\
\hline
\end{tabular}

* Modified Shwachman score (15).

$\dagger$ Medications: 1-pancrease; 2-multivitamins and Aquasol E; 3-tetracycline; 4-trimethoprim/sulfisoxazole; $5-\beta$-adrenergic agents, aerosol and systemic; 6-Colistin by aerosol.
Co., Pittsburgh, PA). When plastic-backed plates were used, the spots were cut out with scissors, placed in scintillation vials and eluted with methanol before counting in the cocktail described above.

\section{RESULTS}

Recovery of product. Commercial $\left[{ }^{14} \mathrm{C}\right]-$ or $\left[{ }^{3} \mathrm{H}\right]-\mathrm{PC}$ or $\mathrm{PE}$ (New England Nuclear Corp.) were used as markers. Two extractions with chloroform resulted in recovery of $78-85 \%$ of radioactive marker: further extractions added little. Following evaporation and chromatography, recovery was $65-75 \%$. Thus, overall recovery was $50-60 \%$ when plastic-backed chromatography plates are used (lower when glass plates are used). The values reported herein are not corrected for recovery.

Evaluation of the assay procedure. In lymphocyte or granulocyte membranes, only $0.1-0.3 \%$ of added radioactivity is incorporated into PM. This amount approaches the level of contamination in commercial radioactive SAM. Washing the $\left[{ }^{3} \mathrm{H}\right]-\mathrm{SAM}$ with $\mathrm{CHCl}_{3}$ or butanol prior to use (done routinely for the assays reported herein) reduced total background radioactivity in the chromatogram by $30-50 \%$. Still, over half the chloroform extractable counts were not found in the PM spot $\left(R_{f}=0.45-0.55\right)$ but were recovered at or near the solvent front $\left(R_{f}>0.9\right)$. These counts increase with time when $\left[{ }^{3} \mathrm{H}\right]-\mathrm{SAM}$ is incubated without tissue at $37^{\circ} \mathrm{C}$ (Fig. 1) and increase at higher $\mathrm{pH}$, consistent with breakdown of $\left[{ }^{3} \mathrm{H}\right]-S A M$ or a contaminant in alkaline medium. Therefore it is important to demonstrate that the counts recovered with the PM carrier have the properties of bona fide product of enzyme-catalyzed reaction.

No radioactivity accumulates in the PM spot with time in the absence of tissue (Fig. 1). Boiling the lymphocyte or granulocyte membranes for $15 \mathrm{~min}$ prior to assay eliminated $80-95 \%$ of all the counts in the PM spot. (All values reported for enzyme activity are for intact enzyme minus boiled control.) Radioactivity in the product was four to 20 times that in the same spot for the boiled control or the zero time point (Figs. 2 and 3). Triplicate samples of reaction product chromatographed in three different

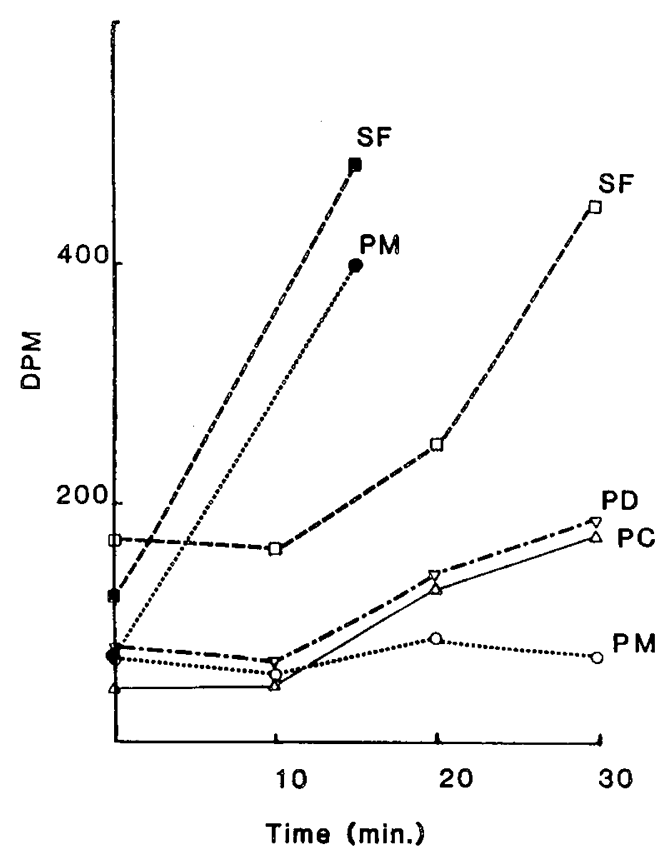

Fig. 1. Accumulation of radioactivity with time in portions of the chromatogram marked by authentic phospholipid carrier. Data are shown from one of five similar experiments. Open symbols indicate radioactivity accumulated in the absence of tissue: closed symbols show accumulation in the presence of lymphocyte membranes. $S F$, solvent front (includes $R_{f}$ values $>0.9$ ). 


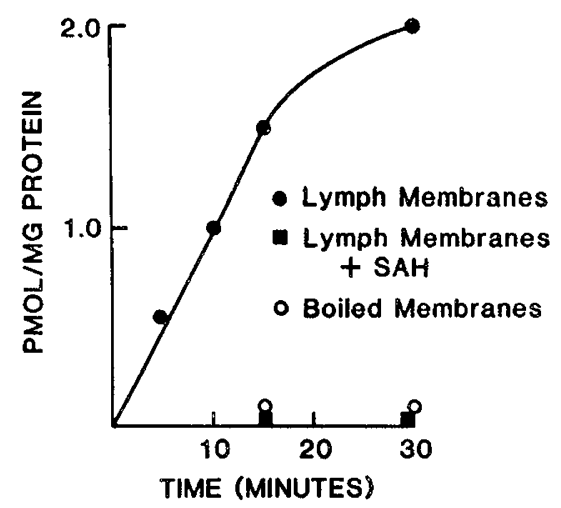

Fig. 2. Production of PM by lymphocyte membranes. Curve shows the mean of three experiments. $S A H$, S-adenosylhomocysteine. "Boiled membranes" were boiled $15 \mathrm{~min}$ before inclusion in assay.

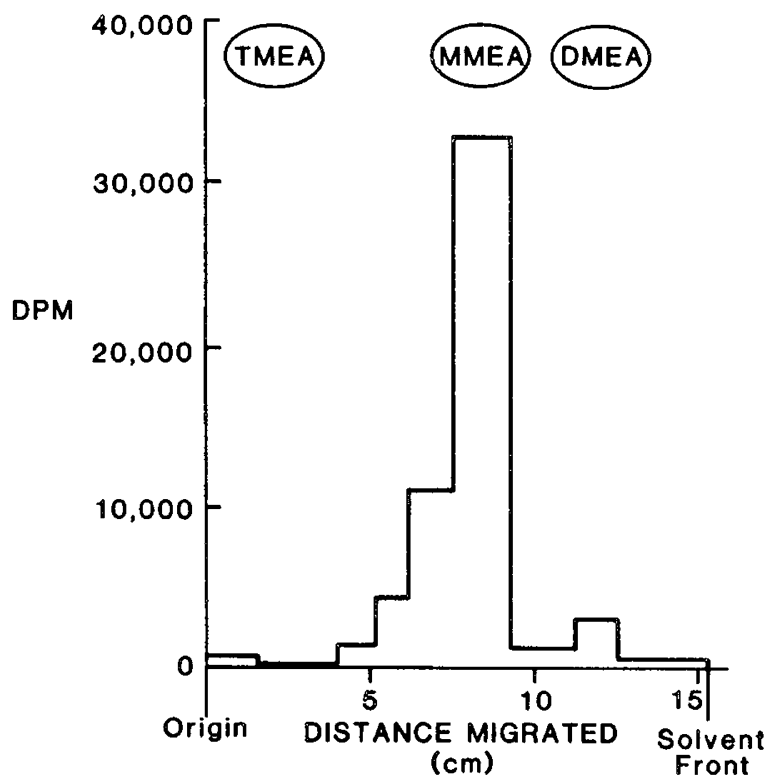

Fig. 3. Distribution of radioactivity in a thin-layer chromatogram of materials derived from hydrolysis $\left(6 \mathrm{~N} \mathrm{HCl}, 3 \mathrm{~h}, 100^{\circ} \mathrm{C}\right)$ of $\mathrm{PM}$ separated during routine assay for PEMT. Stationary phase was silica gel $G$ and developer was 1-propanol: $\mathrm{NH}_{4} \mathrm{OH}, 4: 1$. TMEA, authentic trimethylethanolamine; $D M E A$, authentic dimethylethanolamine; $M M E A$, authentic monomethylethanolamine. Chromatogram illustrates recovery of the majority of counts in PM with MMEA after hydrolysis.

Table 2. Recovery of PM in different chromatography systems

\begin{tabular}{ccc} 
& \multicolumn{2}{c}{ Counts per min in PM } \\
\cline { 2 - 3 } spot \\
\cline { 2 - 3 } Liquid phase* & Trial 1 & Trial 2 \\
\hline I & 645 & 755 \\
II & 637 & 1166 \\
III & 752 & 715 \\
\hline
\end{tabular}

* I = 1-propanol: $\mathrm{CHCl}_{3}$ :propionic acid: $\mathrm{H}_{2} \mathrm{O}, 3: 2: 2: 1$. II = 2-propanol: $\mathrm{CHCl}_{3}$ : propionic acid: $\mathrm{H}_{2} \mathrm{O}: 3: 2: 2: 1$. III $=\mathrm{CHCl}_{3}$ : acetone: methanol: acetic acid: $\mathrm{H}_{2} \mathrm{O}: 10: 4: 2: 2: 1$.

solvent systems, in which the relative $R_{f}$ values for the carrier materials were different, yielded similar counts recovered with carrier PM (Table 2). In a separate experiment, purified PM recovered from the silica gel was hydrolyzed with $6 \mathrm{~N} \mathrm{HCl}$ for 3 $h$ at $100^{\circ} \mathrm{C}$. One volume of methanol was added. The liquid was removed by evaporation and the free base taken up in $\mathrm{CH}_{3} \mathrm{OH}-$ $\mathrm{H}_{2} \mathrm{O}, 1: 1$ containing carrier ethanolamine, monomethylethano- lamine, dimethylethanolamine, and trimethylethanolamine. This material was chromatographed on silica gel using 1-propanol: $\mathrm{NH}_{4} \mathrm{OH}, 4: 1$ as developer, spots visualized with $\mathrm{I}_{2}$ vapor and cut out, extracted with $\mathrm{CH}_{3} \mathrm{OH}: \mathrm{CH}_{3} \mathrm{COOH}: \mathrm{H}_{2} \mathrm{O}, 39: 1: 10$, and counted in ACS scintillant (Amersham Co., Arlington Heights, IL). The radioactivity was recovered largely with the monomethylethanolamine spot (Table 3, Fig. 3) (16), indicating that the $\left[{ }^{3} \mathrm{H}\right]$ label that travelled with $\mathrm{PM}$ on the initial chromatogram was located in the polar head group, as expected.

Properties of lymphocyte PEMT activity. Activity was linear with time over 5-20 min but slowed at 45-60 min. Activity was inhibited $85-90 \%$ by S-adenosylhomocysteine, a competitor for SAM (Fig. 2). Formation of PM is $\mathrm{pH}$-dependent, optimal at $\mathrm{pH}$ 8.0-9.0, and poor at $\mathrm{pH} 7.0$ or $\mathrm{pH} 10.0$. Substrate-velocity curves were performed at concentrations ranging from 1-16 $\mu \mathrm{M}$ SAM: at lower concentrations it is difficult to detect activity reliably, at higher concentrations, significant amounts of PD and PC are formed. At these substrate concentrations there was no increase in radioactivity travelling with PC or PD compared to boiled controls. Double reciprocal plots are linear $(r>0.977)$ (Fig. 4) and give $\mathrm{K}_{\mathrm{m}}=7.01 \pm 2.9 \mu \mathrm{M}$ and apparent $\mathrm{V}_{\max }=0.57 \pm 0.31$ $\mathrm{pmol} / 15 \mathrm{~min} / \mathrm{mg}$ protein for enzyme in lymphocyte membranes from 10 healthy unmedicated volunteers $18-40$ yr old. Activity is stimulated $5-30 \%$ by exogenous PE but does not depend on the addition of exogenous $\mathrm{Mg}^{++}$, although the membranes were not specifically prepared to be magnesium free.

Isoproterenol stimulated PEMT activity in a dose-dependent manner, with maximal stimulation at $10^{-5} \mathrm{M}$ (Fig. 5). Norepinephrine $\left(10^{-4}\right.$ and $\left.10^{-5} \mathrm{M}\right)$ had no effect, and epinephrine $\left(10^{-5}\right.$ $M$ but not lower concentrations) slightly but statistically significantly stimulated PEMT activity. GMPPNP $\left(10^{-4} \mathrm{M}\right)$ significantly inhibited PEMT. However, GMPPNP did not affect the isoproterenol stimulation of PEMT. Propranolol $\left(10^{-5} \mathrm{M}\right)$ inhibited the stimulation by isoproterenol or epinephrine $\left(10^{-5} \mathrm{M}\right)$. IBMX, a phosphodiesterase inhibitor, did not enhance the effect of isoproterenol, and cAMP alone $\left(10^{-6} \mathrm{M}\right)$ or in combination

Table 3. Recovery of monomethylethanolamine (MMEA) from hydrolysis of PM

\begin{tabular}{lccc}
\hline & DPM & $\begin{array}{c}\text { Recovery } \\
\text { (\% previous step) }\end{array}$ & $\begin{array}{c}\text { Recovery } \\
\text { (\% initial) }\end{array}$ \\
\hline PM spots* & 83399 & 100 & 100 \\
PM (extracted) & 76197 & 91 & 91 \\
Total after hydrolysis & 58100 & 76 & 70 \\
MMEA & 52211 & 90 & 63 \\
\hline
\end{tabular}

* PM spots from several experiments were pooled to obtain high initial counts.

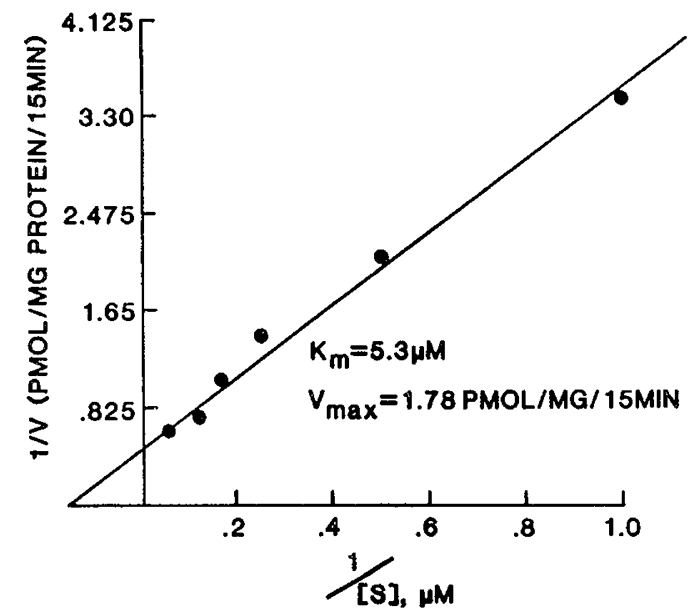

Fig. 4. Representative double reciprocal substrate-velocity plot for PEMT activity in human lymphocyte membranes from a 25 -yr-old healthy volunteer. 


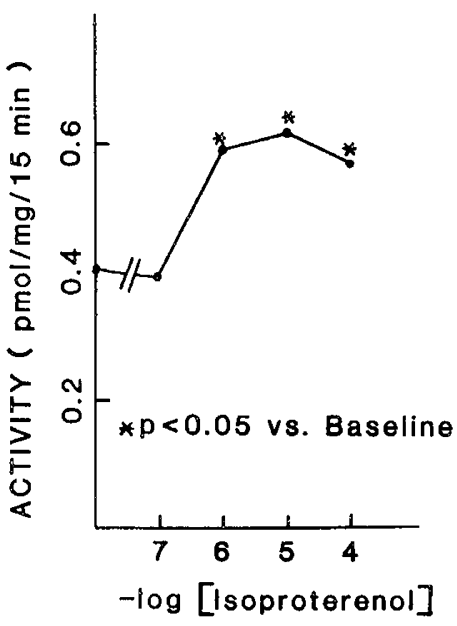

Fig. 5. Response of PEMT to isoproterenol in human lymphocyte membranes. Curve shows the mean of five experiments; bars are SEM. Asterisks indicate significant $(p<0.05)$ differences from baseline values.

with IBMX did not stimulate PEMT. Neither prostaglandin $\mathrm{E}_{1}$ $\left(10^{-8}\right.$ to $\left.10^{-6} \mathrm{M}\right)$ nor concanavalin A $(1 \mu \mathrm{g} / \mathrm{ml})$ stimulated PEMT (Table 4).

Association of activity with lymphocytes. Preparation of lymphocytes on a Ficoll-Hypaque gradient leads to some contamination of the lymphocyte fraction with platelets, even when platelet-rich plasma is removed in an initial centrifugation step, as was done in the present study. However, methods that give platelet-free preparations entail substantial losses of lymphocytes and possibly selection of lymphocyte subpopulations. Platelets contain phospholipid methylating enzymes (17). In order to determine how much contaminating platelets contribute to the activity in lymphocyte preparations, platelets were purified from platelet-rich plasma and homogenized and centrifuged in the same fashion as the lymphocytes. From $150 \mathrm{ml}$ blood, $0.6 \mathrm{mg}$ platelet protein was recovered. PEMT activity was $1.93 \mathrm{pmol} /$ $\mathrm{mg}$ protein/15 min (mean of two determinations). Because 98 to $99 \%$ of platelets were recovered in the platelet-rich plasma and one to three platelets were counted for each lymphocyte in the final preparations, no more than $1-2 \%$ of total blood platelets appear in the lymphocyte preparations. After homogenization and centrifugation, less than $1 \%$ of the recovered protein is platelet derived. Therefore, less than $5 \%$ of the PEMT activity observed in lymphocyte membranes can be attributed to platelet contamination.

Properties of the granulocyte enzyme activity. Activity was linear with time over $5-30 \mathrm{~min}$. Activity was inhibited $>90 \%$ by S-adenosylhomocysteine, a competitor for SAM. Formation of $\mathrm{PM}$ is $\mathrm{pH}$ dependent, optimal at $\mathrm{pH} 8.0-9.5$, and poor at $\mathrm{pH} 7.0$ or $\mathrm{pH}$ 10.0. Substrate-velocity curves were performed at concentrations ranging from $1-16 \mu \mathrm{M}$ SAM: at lower concentrations it is difficult to detect activity reliably, at higher concentrations, significant amounts of PD and PC are formed. At these substrate concentrations, there was no increase in radioactivity traveling with PC or PD compared to boiled controls. Double reciprocal plots are linear $(r>0.945)$ (Fig. 6) and give apparent $\mathrm{K}_{\mathrm{m}}=4.42$ $\pm 2.5 \mu \mathrm{M}$ and apparent $\mathrm{V}_{\max }=0.54 \pm 0.51 \mathrm{pmol} / 15 \mathrm{~min} / \mathrm{mg}$ protein for enzyme in granulocyte membranes from 10 healthy unmedicated volunteers $18-40 \mathrm{yr}$ old. Activity is not stimulated by exogenous PE and does not depend on the addition of exogenous $\mathrm{Mg}^{++}$, although the membranes were not specifically prepared to be magnesium free.

Isoproterenol stimulation of enzyme activity was dose dependent and inhibited by propranolol. Maximal stimulation was not achieved even at $10^{-4} \mathrm{M}$ (Fig. 7). GMPPNP $\left(10^{-4} \mathrm{M}\right)$ stimulated PEMT modestly. However, GMPPNP did not affect the stimulation of PEMT by isoproterenol. The order of potency of $\beta$ adrenergic agonists was isoproterenol $>>$ epinephrine $>$ nor-
Table 4. Lymphocyte PEMT responses

\begin{tabular}{llc}
\hline \multicolumn{1}{c}{ Additions (s) } & $n$ & $\%$ Baseline* \\
\hline Isoproterenol $10^{-5} \mathrm{M}$ & 5 & $155 \dagger$ \\
Isoproterenol $10^{-5} \mathrm{M}$ & 3 & $(91) \ddagger$ \\
+ GMPPNP $10^{-4} \mathrm{M}$ & & $(162) \S$ \\
Epinephrine $10^{-5} \mathrm{M}$ & 5 & $117 \dagger$ \\
Norepinephrine $10^{-5} \mathrm{M}$ & 4 & 104 \\
Isoproterenol $10^{-5} \mathrm{M}$ & 4 & 105 \\
+ Propranolol $10^{-5} \mathrm{M}$ & & \\
Propranolol $10^{-5} \mathrm{M}$ & 4 & 111 \\
Prostaglandin $\mathrm{E}_{1} 10^{-6} \mathrm{M}$ & 3 & 105 \\
GMPPNP $10^{-4} \mathrm{M}$ & 3 & $64 \dagger$ \\
cAMP $10^{-5} \mathrm{M}$ & 3 & 93 \\
cAMP $10^{-5} \mathrm{M}+\mathrm{IBMX} 10^{-4} \mathrm{M}$ & 2 & 109 \\
IBMX $10^{-4} \mathrm{M}$ & 2 & 72 \\
Concanavalin A $1 \mu \mathrm{g} / \mathrm{ml}$ & 4 & 87 \\
\hline
\end{tabular}

* Baseline values determined in the presence of $4 \mu \mathrm{M}$ SAM, after 15 min incubation at $37^{\circ} \mathrm{C}$.

$\dagger$ Significantly different from baseline, paired $t$ test $(p<0.05)$.

$\ddagger$ Percent of control with isoproterenol alone.

$\S$ Percent of control with GMPPNP alone.

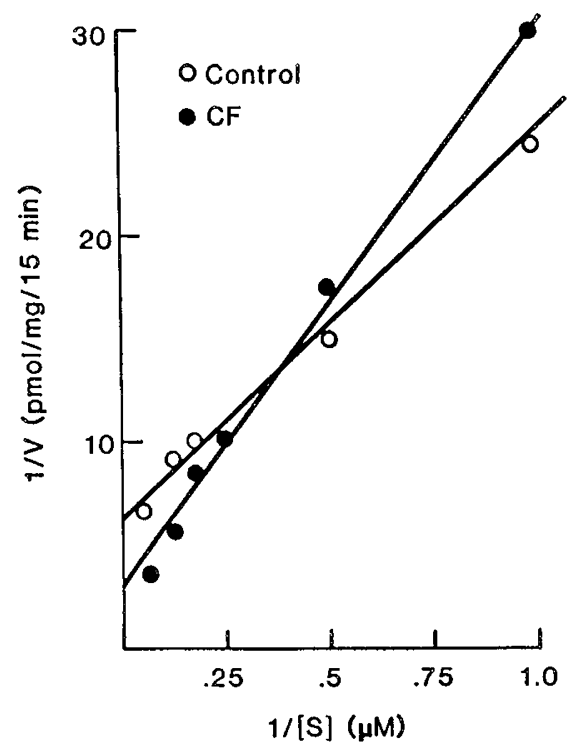

Fig. 6. Representative double reciprocal substrate-velocity plots for PEMT activity in granulocyte membranes from one CF and one control subject.

epinephrine. IBMX did not enhance the effect of isoproterenol, and cAMP alone $\left(10^{-6} \mathrm{M}\right)$ or in combination with IBMX did not stimulate PEMT. Prostaglandin $\mathrm{E}_{1}\left(10^{-6} \mathrm{M}\right)$ inhibited PEMT: activity averaged $78 \%$ of control. There was no stimulation of human granulocyte PEMT by fMLP $\left(10^{-9}\right.$ or $\left.10^{-6} \mathrm{M}\right)$ or by serum-treated zymosan (Table 5).

Comparison of CF and control PEMT. The reproducibility of this assay from day to day for the same individual was assesed. Maximum coefficients of variation (SD/mean of at least three determinations on separate days for two to five normal subjects) were as follows: for lymphocyte enzyme $\mathrm{K}_{\mathrm{m}}, 10 \%$; lymphocyte specific activity, $25 \%$; granulocyte enzyme $\mathrm{K}_{\mathrm{m}}, 11 \%$; granulocyte specific activity, $17 \%$.

Like the larger groups of CF patients reported previously (4, $34,35)$, these CF subjects had reduced cAMP response to isoproterenol $\left(10^{-5} \mathrm{M}\right.$ ) compared to healthy controls (Table 6). However, when $C F$ subjects were compared with controls, no consistent differences in PEMT could be demonstrated. Means for specific activity did not differ between the groups, nor could consistent trends be demonstrated (Tables 7 and 8). The apparent $\mathrm{K}_{\mathrm{m}}$ for SAM was lower in CF lymphocyte membranes than in 


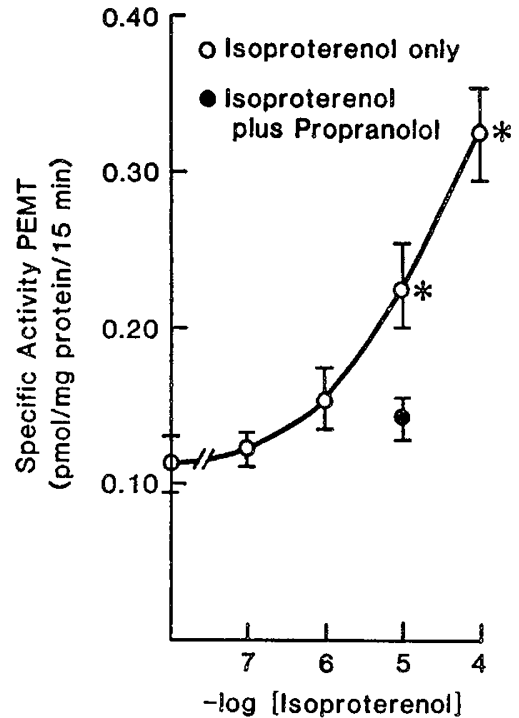

Fig. 7. Response of PEMT to isoproterenol in human granulocyte membranes. Curve shows the mean of six experiments; bars are SEM. Asterisks indicate significant $(p<0.05)$ differences from baseline.

Table 5. Granulocyte PEMT responses

\begin{tabular}{llc}
\hline \multicolumn{1}{c}{ Addition(s) } & $n$ & $\%$ Baseline* \\
\hline Isoproterenol $10^{-5} \mathrm{M}$ & 6 & $197 \dagger$ \\
Isoproterenol $10^{-5} \mathrm{M}$ & 3 & $(86) \ddagger$ \\
+ GMPPNP $10^{-4} \mathrm{M}$ & & $(240) \S$ \\
Epinephrine $10^{-5} \mathrm{M}$ & 3 & $143 \dagger$ \\
Norepinephrine $10^{-5} \mathrm{M}$ & 3 & $120 \dagger$ \\
Isoproterenol $10^{-5} \mathrm{M}$ & 6 & 132 \\
+ Propranolol $10^{-5} \mathrm{M}$ & & \\
Propranolol $10^{-5} \mathrm{M}$ & 6 & 110 \\
Prostaglandin $\mathrm{E}_{1} 10^{-6} \mathrm{M}$ & 3 & $78 \dagger$ \\
cAMP $10^{-5} \mathrm{M}$ & 4 & 78 \\
cAMP $10^{-5} \mathrm{M}+\mathrm{IBMX} 10^{-4} \mathrm{M}$ & 2 & 113 \\
GMPPNP $10^{-4} \mathrm{M}$ & 3 & 123 \\
IBMX $10^{-4} \mathrm{M}$ & 2 & 65 \\
fMLP $10^{-9} \mathrm{M}$ & 3 & 108 \\
fMLP $10^{-6} \mathrm{M}$ & 3 & 85 \\
Serum-treated zymosan & 4 & 110 \\
\hline
\end{tabular}

* Baseline values were determined with $4 \mu \mathrm{M}$ SAM, after 15 min incubation at $37^{\circ} \mathrm{C}$.

$\dagger$ Significantly different from baseline, paired $t$ test $(p<0.05)$.

$\$$ Percent of control with isoproterenol alone.

$\S$ Percent of control with GMPPNP alone.

the controls ( $p=0.051$ ), but in granulocyte membranes, the $\mathrm{K}_{\mathrm{m}}$ for SAM was the same for CF and control subjects.

\section{DISCUSSION}

Human lymphocyte membranes contain PEMT activity with apparent $\mathrm{K}_{\mathrm{m}}$ for SAM of $7.01 \mu \mathrm{M}$, and specific activity at least $0.57 \mathrm{pmol} / \mathrm{mg} / 15 \mathrm{~min}$ (values are not corrected for recovery). Human granulocyte membranes also contain PEMT activity, with apparent $\mathrm{K}_{\mathrm{m}}$ for SAM $4.4 \mu \mathrm{M}$ and specific activity at least $0.54 \mathrm{pmol} / \mathrm{mg} / 15 \mathrm{~min}$. These values are comparable to those reported for plasma membrane PEMT in human erythrocytes, mast cells, and cultured HeLa cells (6-13), but are considerably lower than PEMT activity in rat liver or adrenal microsomes $(16,18-20)$. Nevertheless, the enzyme studied herein produces bona fide PM, as identified in three different thin-layer chromatography system (Table 2 ) and by chemical analysis of its hydrolytic products (Fig. 3), and PM is produced only in the presence of active (not heat denatured) enzyme (Fig. 2). This activity has other properties expected of enzyme-catalyzed reac-
Table 6. Isoproterenol $\left(10^{-5} \mathrm{M}\right)$-stimulated cAMP production (\% control)

\begin{tabular}{|c|c|c|c|c|c|}
\hline \multicolumn{3}{|c|}{ CF subjects } & \multicolumn{3}{|c|}{ Controls } \\
\hline No. & Lymphocyte & Granulocyte & No. & Lymphocyte & Granulocyte \\
\hline \multirow[t]{2}{*}{1} & 210 & 200 & $1 \mathrm{a}$ & 440 & 180 \\
\hline & & & $1 \mathrm{~b}$ & 330 & 260 \\
\hline \multirow[t]{2}{*}{2} & 141 & 100 & $2 a$ & 391 & 160 \\
\hline & & & $2 b$ & 718 & 545 \\
\hline \multirow[t]{2}{*}{3} & 122 & 170 & $3 a$ & 310 & 202 \\
\hline & & & $3 b$ & 560 & 260 \\
\hline \multirow[t]{3}{*}{4} & 119 & 131 & $4 a$ & 280 & 310 \\
\hline & & & $4 \mathrm{~b}$ & 365 & 300 \\
\hline & $123 \pm 79^{*}$ & $150 \pm 44^{*}$ & & $424 \pm 148$ & $277 \pm 121$ \\
\hline
\end{tabular}

* Different from control $p<0.05$.

Table 7. PEMT activity of lymphocytes

\begin{tabular}{|c|c|c|c|c|c|}
\hline \multicolumn{3}{|c|}{ CF subjects } & \multicolumn{3}{|c|}{ Controls } \\
\hline No. & $\begin{array}{c}\mathrm{K}_{\mathrm{m}} \\
(\mu \mathrm{M}) \\
\end{array}$ & $\begin{array}{c}\mathrm{V}_{\max } \\
(\mathrm{pmol} / \\
\mathrm{mg} / 15 \mathrm{~min})\end{array}$ & No. & $\begin{array}{c}\mathrm{K}_{\mathrm{m}} \\
(\mu \mathrm{M}) \\
\end{array}$ & $\begin{array}{c}\mathrm{V}_{\max } \\
(\mathrm{pmol} / \\
\mathrm{mg} / 15 \mathrm{~min})\end{array}$ \\
\hline \multirow[t]{2}{*}{1} & 4.9 & 0.45 & $1 \mathrm{a}$ & 7.2 & 1.46 \\
\hline & & & $1 b$ & 10.6 & 0.72 \\
\hline \multirow[t]{2}{*}{2} & 3.3 & 0.55 & $2 \mathrm{a}$ & 4.5 & 0.44 \\
\hline & & & $2 b$ & 12.9 & 0.19 \\
\hline \multirow[t]{2}{*}{3} & 4.4 & 0.19 & $3 a$ & 7.3 & 0.41 \\
\hline & & & $3 b$ & 3.6 & 0.35 \\
\hline \multirow[t]{3}{*}{4} & 1.7 & 0.87 & $4 a$ & 4.1 & 0.40 \\
\hline & & & $4 b$ & 10.4 & 0.47 \\
\hline & $3.6 \pm 1.2$ & $0.52 \pm 0.24$ & & $7.6 \pm 3.2$ & $0.56 \pm 0.37$ \\
\hline
\end{tabular}

Table 8. PEMT activity of granulocytes

\begin{tabular}{|c|c|c|c|c|c|}
\hline \multicolumn{3}{|c|}{ CF Subjects } & \multicolumn{3}{|c|}{ Controls } \\
\hline No. & $\begin{array}{c}\mathrm{K}_{\mathrm{m}} \\
(\mu \mathrm{M})\end{array}$ & $\begin{array}{c}\mathrm{V}_{\max } \\
(\mathrm{pmol} / \\
\mathrm{mg} / 15 \mathrm{~min})\end{array}$ & No. & $\begin{array}{c}\mathrm{K}_{\mathrm{m}} \\
(\mu \mathrm{M})\end{array}$ & $\begin{array}{c}\mathrm{V}_{\max } \\
(\mathrm{pmol} / \\
\mathrm{mg} / 15 \mathrm{~min})\end{array}$ \\
\hline \multirow[t]{2}{*}{1} & 3.0 & 0.22 & 1a & 2.6 & 0.25 \\
\hline & & & $1 b$ & 4.5 & 0.11 \\
\hline \multirow[t]{2}{*}{2} & 4.1 & 0.66 & $2 a$ & 2.6 & 0.15 \\
\hline & & & $2 \mathrm{~b}$ & 3.9 & 0.22 \\
\hline \multirow[t]{2}{*}{3} & 8.3 & 0.30 & $3 a$ & 5.2 & 0.14 \\
\hline & & & $3 b$ & 6.9 & 0.47 \\
\hline \multirow[t]{3}{*}{4} & 3.4 & 0.09 & $4 a$ & 5.5 & 0.22 \\
\hline & & & $4 b$ & 1.7 & 0.52 \\
\hline & $4.7 \pm 2.1$ & $0.32 \pm 0.21$ & & $4.1 \pm 1.6$ & $0.26 \pm 0.14$ \\
\hline
\end{tabular}

tion, including $\mathrm{pH}$ dependence, inhibition by a competitor of SAM (S-adenosylhomocysteine) (Fig. 2), and time and substrateconcentration dependence (Figs. 2, 5, and 6). However, enzyme activity is low, and it is difficult to imagine that the minor changes in lipid composition which could be produced by this system substantially affect the membrane's physical properties (14). However, local rearrangement of lipids about specific proteins could alter their function. This hypothesis is supported by data which indicate that maximal stimulation of phospholipid methylation in $\mathrm{C} 6$ astrocytoma cells by $\beta$-adrenergic agonists and diazepam analogs is additive, suggesting that these two receptors do not activate the same pool of enzyme (21).

The results reported herein differ somewhat from those of Niwa et al. $(22,23)$, who found that nearly all the chloroformextractable counts in lymphocyte and granulocyte membrane methylation assays were in methylated phospholipids. In our assays, fewer than $50 \%$ of the chloroform-extractable counts are in bona fide product: most travel at or near the solvent front, and some of them can be generated even in the absence of tissue 
(Fig. 1). Thus it was necessary to chromatograph every sample to identify the product and to subtract the counts present in a boiled control in order to assess enzyme activity accurately. Others have also observed the same phenomenon in phospholipid methylation assays. For example, Laychock (24) reported that, in rat pancreatic islets, only $15 \%$ of lipid-extractable counts were recovered in methylated phospholipid product. Recently, nonenzymatic methylation of phosphatidylethanolamine under conditions comparable to those used here has been demonstrated (25). Thus, although tedious, separation of product for each assay tube appears to be prudent. Results obtained in other ways may be suspect.

Although early reports in intact mouse lymphocytes suggested that concanavalin A stimulates phospholipid methylation and may be required for lymphocyte transformation (26), in the present study PEMT was not stimulated by concanavalin $\mathrm{A}$ in human lymphocyte membranes. This finding is in general accord with those of Niwa et al. $(22,23)$, who find minimal stimulation of phospholipid methylation by concanavalin $\mathrm{A}$ in sonicates of human lymphocytes, and with the results of others who find no response of human lymphocyte phospholipid methylation to concanavalin A $(27,28)$.

Niwa et al. $(22,23)$ report that opsonized zymosan stimulates neutrophil phospholipid methylation, but such stimulation was not observed in the present study. Differences in preparative methods, assay conditions, and product identification may account for the different results. In particular, Niwa's assay conditions favored formation of PC, and relatively little PM. Inhibition of turnover of methylated phospholipids in neutrophils by fMLP was reported (29). However, no effect on synthesis was observed. In the present study. methylated phospholipid synthesis was not affected by fMLP, in agreement with prior results.

In tissues in which the coupling of the $\beta$-adrenergic receptor to adenylate cyclase is facilitated by phospholipid methylation, $\beta$-adrenergic agonists stimulate phospholipid methylation $(6,7$, 30 ). In human lymphocyte and granulocyte membranes, stimulation of PEMT by $\beta$-adrenergic agents is dose dependent (Figs. 5 and 7), propranolol inhibitable, has order of potency of agonists typical of $\beta_{2}$-adrenergic systems (isoproterenol> epinephrine $>$ norepinephrine) (Tables 4 and 5), and occurs under conditions under which production of cAMP was not expected (no substrate available, no guanine nucleotides added). Exogenous guanine nucleotides did not enhance the ability of isoproterenol to stimulate PEMT. Moreover, PEMT activity was not stimulated by addition of cAMP (Tables 4 and 5). Stimulation of PEMT by isoproterenol may be a non-cAMP mediated $\beta$ adrenergic effect, like inhibition of magnesium transport (31) and the initial stages of desensitization, the uncoupling of receptor and cyclase. Although these membrane preparations contain many subcellular fractions, stimulation of PEMT by isoproterenol but not cAMP suggests that at least some of the enzyme is in the plasma membrane. In tissues in which phospholipid methylation occurs in the microsome (e.g. liver), it is stimulated by cAMP, whereas in preparations in which PEMT is thought to be associated with the plasma membrane, there is no stimulation by cAMP (32).

Therefore, PEMT occurs in human lymphocyte and granulocyte (plasma) membranes and is stimulated by $\beta$-adrenergic agents. The $\beta_{2}$-adrenergic system in CF leukocytes fails to increase cellular production of cAMP to the same extent as in normal leukocytes $(4,33,34$; Table 6$)$. CF heterozygotes have intermediate response $(4,33)$. Although a similar coupling defect does not appear to be the cause of the reduced $\beta$-adrenergic responses in some other $\mathrm{CF}$ tissues $(35,36)$, the findings in leukocytes have been reproduced in two separate laboratories and, importantly, occur in asymptomatic parents as well $(4,32)$. This leukocyte receptor-cyclase coupling defect might reflect a more fundamental inherited membrane or regulatory abnormality in CF. The presence of PEMT in leukocyte membranes, and its stimulation by the $\beta_{2}$-adrenergic system, suggests that lym- phocyte and granulocyte membranes are a convenient system in which to test the hypothesis that in CF, PEMT activity is reduced.

This hypothesis is attractive because PEMT has been reported to facilitate coupling of $\beta$-adrenergic receptors to adenylate cyclase (6-9), and in lymphocytes and granulocytes from CF patients such coupling appears to be impaired (4). In addition, PEMT stimulates human erythrocyte calcium ATPase (10), and the activity of this enzyme is reduced in CF (3). Also, PEMT, along with PC-forming enzyme, appears to be required for stimulus secretion coupling $(12,13)$, which may be disordered in $\mathrm{CF}$ (5). In addition, Markovac and Erickson (37) report that variation in PEMT activity in mice is genetically determined. Thus, PEMT may be an important genetically controlled regulatory membrane enzyme, and its activity in $\mathrm{CF}$ is of interest.

However, no reduction in PEMT activity was found in CF in lymphocyte or granulocyte membranes. In lymphocytes, the $\mathrm{K}_{\mathrm{m}}$ for SAM was somewhat reduced in CF preparations, but this is inconsistent with the hypothesis that overall PEMT activity is reduced in $C F$, and the $K_{m}$ for SAM for PEMT is normal in granulocytes. It is possible that the crude membranes prepared from CF patients and controls contain different proportions of plasma membrane or different amounts of endogenous substrate (PE), thereby altering the apparent specific activity for PEMT. However, membranes prepared in the same way display the CF $\beta$-adrenergic defect. If reduced PEMT activity accounts for the impaired coupling, it should be manifest in these preparations. Because it was not, reduced PEMT activity will not explain the diverse disorders of membrane function in $\mathrm{CF}$.

Acknowledgments. The excellent technical assistance of Vanessa Turi and Andrea Billups is gratefully acknowledged.

\section{REFERENCES}

1. Stutts MJ, Cotton CU, Yankaskas JR, Cheng E, Knowles MR, Gatzy JT, Boucher RC 1985 Chloride uptake into cultured airway epithelial cells from cystic fibrosis patients and normal individuals. Proc Natl Acad Sci USA $82: 6677-6681$

2. Quinton PM, Bijman J 1983 Higher bioelectrical potentials due to decreased chloride absorption in the sweat glands of patients with cystic fibrosis. $\mathrm{N}$ Engl J Med 308:1185-1189

3. Katz S 1978 Calcium and sodium transport processes in patients with cystic fibrosis. I. A specific decrease in $\mathrm{Mg}^{2+}$-dependent, $\mathrm{Ca}^{2+}$-adenosine triphosphatase activity in erythrocyte membranes from cystic fibrosis patients. Pediatr Res 12:1033-1037

4. Davis PB, Dieckman L, Boat TF, Stern RC, Doershuk CF 1983 Beta-adrenergic receptors in lymphocytes and granulocytes from patients with cystic fibrosis. J Clin Invest 71:1787-1795

5. Davis PB, di Sant'Agnese 1980 A review. Cystic fibrosis at forty-quo vadis? Pediat Res 14:83-87

6. Hirata F. Strittmatter WJ, Axelrod J 1979 Beta-adrenergic receptor agonists increase phospholipid methylation, membrane fluidity, and beta-adrenergic receptor-adenylate cyclase coupling. Proc Natl Acad Sci USA 76:368-372

7. Hirata F, Tallman JF Henneberry RC, Mallorga P, Strittmatter WJ, Axelrod J 1981 Phospholipid methylation: a possible mechanism of signal transduction across biomembranes. In: Oxender D, Blume A, (eds) Membrane Transport and Neuroreceptors, Alan R. Liss, Inc., New York, NY, pp 383388

8. Munzel P, Koschel K 1982 Aleration in phospholipid methylation and impairment of signal transmission in persistently paramyxovirus-infected $\mathrm{C} 6$ rat glioma cells. Proc Natl Acad Sci USA 79:3692-3696

9. Tallman JF, Henneberry RC, Hirata F, Axelrod J 1979. Control of $\beta$-adrenergic receptors in HeLa cells. In: Usdin E (ed) Catecholamines: Basic and Clinical Frontiers, Vol 1. Pergamon, Oxford, pp 489-497

10. Strittmatter WJ, Hirata F, Axelrod J 1979 Increased $\mathrm{Ca}^{2+}$-ATPase activity associated with methylation of phospholipids in human erythrocytes. Biochem Biophys Res Comm 88:147-153

11. Strittmatter WJ, Hirata F, Axelrod J 1979 Phospholipid methylation unmasks cryptic beta-adrenergic receptors in rat reticulocytes. Science 204:1205-1207

12. Ishizaka T, Hirata F, Ishizaka K, Axelrod J 1980 Stimulation of phospholipid methylation, $\mathrm{Ca}^{2+}$ influx, and histamine release by bridging of $\operatorname{lgE}$ receptors on rat mast cells. Proc Natl Acad Sci USA 77:1903-1906

13. McGivney A, Morita Y, Crews FT, Hirata F, Axelrod J, Siraganian RP 1981 Phospholipase activation in the IgE-mediated and $\mathrm{Ca}^{2+}$ ionophore A23187induced release of histamine from rat basophylic leukemia cells. Arch Biochem Biophys 212:572-580

14. Vance DE, Druijff B 1980 The possible functional significance of phosphatidylethanolamine methylation. Nature 288:277-279

15. Doershuk CF, Matthews LW, Tucker AS, Nudelman H, Eddy TG, Wise M, 
Spector S 1964 A five-year clinical evaluation of a therapeutic program for patients with cystic fibrosis. J Pediatr 65:677-684

16. Schneider WJ, Vance DE 1979 Conversion of phosphatidylethanolamine to phosphatidylcholine in rat liver. J Biol Chem 254:3886-3892

17. Hotchkiss A, Jordan JV, Hirata F, Shulman NR, Axelrod J 1981 Phospholipid methylation and human platelet function. Biochem Pharmacol 30:20892095

18. Hirata F. Axelrod J 1980 Phospholipid methylation and biological signal transmission. Science 209:1082-1090

19. Hoffman DR, Cornatzer WE 1981 Microsomal phosphatidylethanolamine methyltransferase: some physical and kinetic properties. Lipids 16:533-540

20. Hirata F, Viveros OH, Diliberto EJ, Axelrod J 1978 Identification and properties of two methyltransferases in conversion of phosphatidylethanolamine to phosphatidylcholine. Proc Natl Acad Sci USA 75:1718-1721

21. Strittmatter WJ, Hirata F, Axelrod J, Mallorga P, Tallman JF, Henneberry RC 1979 Benzodiazepine and beta-adrenergic receptor ligands independently stimulate phospholipid methylation. Nature (Lond) 282:857-859

22. Niwa Y, Sakane T, Taniguchi S 1984 Phospholipid transmethylation in the membrane of human neutrophils and lymphocytes. Arch Biochem Biophys 234:7-14

23. Niwa Y, Sakane T, Yamamoto S. Tadashi K, Taniguchi S 1985 Methyltransferase and phospholipase $A_{2}$ activity in membranes of neutrophils and lymphocytes from patients with bacterial and viral infections. Inflammation 9:53-65

24. Laychock SG 1985 Phosphatidylethanolamine N-methylation and insulin release in isolated pancreatic islets of the rat. Mol Pharmacol 27:66-73

25. Bansal VS, Kanfer JN 1985 Chemical methylation of phosphatidylethanolamine by S-adenosylmethionine. Biochem Biophys Res Comm 128:411-416

26. Hirata F, Toyoshima S, Axelrod J, Waxdal MJ 1980 Phospholipid methylation: A biochemical signal modulating lymphocyte mitogenesis. Proc Natl Acad Sci USA 77:862-865

27. Moore JP, Smith GA, Hesketh TR, Metcalfe JC 1982 Early increases in phospholipid methylation are not necessary for the mitogenic stimulation of lymphocytes. J Biol Chem 257:8183-8189

28. Parola AH, Kaplan JH, Lockwood SH, Uzgiris EE 1981 Activation of human lymphocytes by concanavalin $A$ or purified protein derivative results in no alteration of fluorescence polarization of lipid probes although the electrophoretic mobility of the cells is changed. Biochem Biophys Acta 649:616624

29. Hirata F, Corcoran BA, Venkatasubramanian K, Schiffman E, Axelrod J 1979 Chemoattractants stimulate degradation of methylated phospholipids and release of arachidonic acid in rabbit leukocytes. Proc Natl Acad Sci USA $76: 2640-2643$

30. Zawad J, Brown FC 1984 Beta-adrenergic coupled phospholipid methylation A possible role in withdrawal from chronic ethanol. Biochem Pharm 33:3799-3805

31. Maguire ME, Erdos JT 1980 Inhibition of magnesium uptake by beta-adrenergic agonists and prostaglandin $E_{1}$ is not mediated by cyclic AMP. J Biol Chem 255:1030-1035

32. Mato JM, Alemany S 1983 What is the function of phospholipid N-methylation? Biochem J 213:1-10

33. Galant SP, Norton L, Herbst J, Wood C 1981 Impaired beta adrenergic receptor binding and function in cystic fibrosis neutrophils. J Clin Invest 68:253-258

34. Davis PB, Braunstein M, Jay C 1978 Decreased adenosine $3^{\prime}: 5^{\prime}$ cyclic monophosphate response to isoproterenol in cystic fibrosis leukocytes. Pediatr Res 12:703-707

35. Sato K, Sato F 1984 Defective beta-adrenergic response of cystic fibrosis sweat glands in vivo and in vitro. $\mathrm{J}$ Clin Invest 73:1763-1771

36. Knowles MR, Stutts MJ, Spock A, Fischer N, Gatzy JT, Boucher RC 1983 Abnormal ion permeation through cystic fibrosis respiratory epithelium. Science 221:1067-1070

37. Markovac J, Erickson RP 1985 The genetics of hormone-induced cyclic AMP production and phospholipid N-methylation in inbred strains of mice. Genet Res 45:167-177 